Research article

Open Access

\title{
Combined effects of single nucleotide polymorphisms TP53 R72P and MDM2 SNP309, and p53 expression on survival of breast cancer patients
}

\author{
Marjanka K Schmidt1', Johanna Tommiska², Annegien Broeks¹, Flora E van Leeuwen1, Laura J Van't \\ Veer ${ }^{1}$, Paul DP Pharoah ${ }^{3}$, Douglas F Easton ${ }^{3}$, Mitul Shah ${ }^{3}$, Manjeet Humphreys ${ }^{3}$, Thilo Dörk ${ }^{4}$, \\ Scarlett A Reincke ${ }^{4}$, Rainer Fagerholm² ${ }^{2}$ Carl Blomqvist ${ }^{5}$ and Heli Nevanlinna ${ }^{2}$
}

\author{
1Departments of Epidemiology, Experimental Therapy and Pathology, Netherlands Cancer Institute, The Netherlands, Plesmanlaan 121, 1066 CX \\ Amsterdam, The Netherlands \\ 2Department of Obstetrics and Gynecology, Helsinki University Central Hospital (HUCH), Haartmaninkatu 8, 00290 Helsinki, Finland \\ ${ }^{3}$ Strangeway's Research Laboratory, Worts Causeway, CB1 8RN Cambridge, UK \\ ${ }^{4}$ Hannover Medical School, Departments of Gynaecology and Radiation Oncology, Carl-Neuberg-Straße 1, 30625 Groß-Buchholz, Hannover, \\ Germany \\ ${ }^{5}$ Department of Oncology, Helsinki University Central Hospital (HUCH), Haartmaninkatu 8, 00290 Helsinki, Finland
}

Corresponding author: Heli Nevanlinna, Heli.Nevanlinna@hus.fi

Received: 7 Jul 2009 Revisions requested: 3 Sep 2009 Revisions received: 9 Dec 2009 Accepted: 18 Dec 2009 Published: 18 Dec 2009

Breast Cancer Research 2009, 11:R89 (doi:10.1186/bcr2460)

This article is online at: http://breast-cancer-research.com/content/11/6/R89

(c) 2009 Schmidt et al.; licensee BioMed Central Ltd.

This is an open access article distributed under the terms of the Creative Commons Attribution License (http://creativecommons.org/licenses/by/2.0), which permits unrestricted use, distribution, and reproduction in any medium, provided the original work is properly cited.

\begin{abstract}
Introduction Somatic inactivation of the TP53 gene in breast tumors is a marker for poor outcome, and breast cancer outcome might also be affected by germ-line variation in the TP53 gene or its regulators. We investigated the effects of the germ-line single nucleotide polymorphisms TP53 R72P $(215 \mathrm{G}>\mathrm{C})$ and MDM2 SNP309 $(-410 \mathrm{~T}>\mathrm{G})$, and p53 protein expression in breast tumors on survival.

Methods We pooled data from four breast cancer cohorts within the Breast Cancer Association Consortium for which both TP53 R72P and MDM2 SNP309 were genotyped and follow-up was available $(n=3,749)$. Overall and breast cancerspecific survival analyses were performed using Kaplan-Meier analysis and multivariate Cox's proportional hazards regression models.
\end{abstract}

Results Survival of patients did not differ by carriership of either germ-line variant, R72P $(215 \mathrm{G}>\mathrm{C})$ or SNP309 $(-410 \mathrm{G}>\mathrm{T})$ alone. Immunohistochemical p53 staining of the tumor was available for two cohorts ( $n=1,109$ patients). Survival was worse in patients with p53-positive tumors $(n=301)$ compared to patients with p53-negative tumors $(n=808)$; breast cancer- specific survival: HR $1.6(95 \% \mathrm{Cl} 1.2$ to 2.1$), P=0.001$. Within the patient group with p53-negative tumors, TP53 rare homozygous (CC) carriers had a worse survival than G-allele (GG/GC) carriers; actuarial breast cancer-specific survival $71 \%$ versus $80 \%, P=0.07$; HR 1.8 (1.1 to 3.1 ), $P=0.03$. We also found a differential effect of combinations of the two germ-line variants on overall survival; homozygous carriers of the G-allele in MDM2 had worse survival only within the group of TP53 Callele carriers; actuarial overall survival (GG versus TT/TG) $64 \%$ versus $75 \%, P=0.001$; HR (GG versus TT) 1.5 (1.1 to 2.0 ), $P$ $=0.01$. We found no evidence for a differential effect of MDM2 SNP309 by 553 protein expression on survival.

Conclusions The TP53 R72P variant may be an independent predictor for survival of patients with p53-negative tumors. The combined effect of TP53 R72P and MDM2 SNP309 on survival is in line with our a priori biologically-supported hypothesis, that is, the role of enhanced DNA repair function of the TP53 Provariant, combined with increased expression of the Mdm2 protein, and thus overall attenuation of the p53 pathway in the tumor cells.

ABCS: Amsterdam Breast Cancer Study; ER: estrogen receptor; HABCS: Hannover Breast Cancer Study; HEBCS: Helsinki Breast Cancer Study; HR: hazard ratio; SD: standard deviation; SEARCH: Studies of Epidemiology and Risk Factors in Cancer Heredity; TMA: tissue micro array. 


\section{Introduction}

Breast cancer outcome may be affected by germ-line variants in genes that play a role in DNA damage control and repair such as TP53 (R72P) and MDM2 (SNP309) [1,2]. The Mdm2 protein is a negative regulator of the tumor suppressor protein p53 [3]. The R72P $(215 \mathrm{G}>\mathrm{C})$ polymorphism of the TP53 gene is located in a proline-rich region of p53 suggested to be required for the growth suppression activity of p53 [4] and for its ability to induce apoptosis [5]. The two variant protein forms, R72 (arginine) and 72P (proline), have been shown to differ in their biological functions: the R72 variant is a stronger and faster inducer of apoptosis than the $72 \mathrm{P}$ variant $[6,7]$. The $72 \mathrm{P}$ variant also binds more efficiently to iASPP, an inhibitor of pro-apoptotic function of $\mathrm{p53}$, which may be another reason for the inferiority in apoptosis induction of this variant [8]. The $72 \mathrm{P}$ variant has been found to be more efficient in inducing cell-cycle arrest [7] and DNA repair [9] than the R72 variant which may protect tumor from chemotherapy-induced apoptosis.

Previous studies have shown that the R72P polymorphism is not associated with increased breast cancer risk $[1,10,11]$. However, an association of R72P with breast cancer survival has been suggested, though with inconsistent results and possibly only in patients with p53-negative tumors [10-16]. It has also been suggested that patients with the Pro/Pro genotype are less sensitive to anthracycline-based treatment than those with the Arg/Pro or Arg/Arg genotype [14,16], in line with the Pro-allele being more efficient in cell-cycle arrest [7] and DNA repair [9] induction.

A common single nucleotide polymorphism in the MDM2 promoter region, a $\mathrm{T}$ to $\mathrm{G}$ change at nucleotide 309 in the first intron (-410G>T; named SNP309), has been shown to create an improved Sp1 binding site, leading to increased expression of the Mdm2 protein and thus attenuation of the p53 pathway and accelerated tumor formation in individuals carrying a germ-line p53 mutation [17-19]. A number of small studies revealed an inconsistent association between SNP309 and breast cancer risk (see overview in [1], and [20,21]). However, we have shown in a large pooled analyses of the Breast Cancer Association Consortium series that there is no general association of SNP309 with breast cancer, nor if stratified by estrogen receptor (ER) [1].

In two small studies no association between breast cancer survival and MDM2 SNP309 genotype alone was found $[13,22]$. However, the results of one of those studies suggested a differential effect of MDM2 SNP309 genotype by tumor p53 status (mutant p53 or aberrant protein expression) on breast cancer survival [22]. Though MDM2 SNP309 has been implicated to affect survival in other tumors (for example, [23]), as far as we know there are no other publications on breast cancer outcome and this polymorphism, except for a recent publication in $B R C A 1 / 2$ carriers of Ashkenazi origin [24]. Our aim was to investigate the combined effects of MDM2 SNP309 and TP53 R72P polymorphisms and p53 protein expression on breast cancer survival.

\section{Materials and methods Clinico-pathologic data and genotyping}

Breast cancer cases from four European studies within the Breast Cancer Association Consortium were included in this analysis (Table 1) $[1,25]$. Patients that were genotyped for MDM2 SNP309 and TP53 R72P from studies with follow-up data were included [1]. Patient selection criteria, participation rates and information on the collection of follow-up and clinical data are shown in Table 1. P53 protein expression data were available for two of the four studies (Table 1). Immunohistochemical staining of TMA slides was performed with a mouse monoclonal anti-human p53-antibody (DO-7, DAKO) (Table 1). Missing p53 data could be attributed to missing tumor blocks, loss of cores in the slicing or staining process or cores not containing enough tumor material. P53 protein expression scoring and MDM2 SNP309 and TP53 R72P genotyping were performed blinded to the survival status of the patients. Genotyping assays were performed by each group separately [1] (see Table 1 for assay description). Primer (and probe) sequences are available from the authors upon request. Methods and results in this paper are reported following the REMARK recommendations [26]. All studies were approved by the appropriate (Medical) Ethical Research Committees.

\section{Statistical analyses}

Univariate analyses of survival were performed by calculating Kaplan-Meier survival curves and comparing subsets of patients using log-rank test. To explore the effects of several variables and their combined effects on survival, multivariate Cox's proportional hazards regression models were used (reported as Hazard Ratio (HR) with 95\% confidence interval). Results are reported for one polymorphisms stratified by the other polymorphisms or p53 expression, adjusted for other covariates. Interaction terms were tested by Cox regression models including the main effects ( $2 \mathrm{df}$ each), interaction terms, for example, four interaction terms for both polymorphisms, and other covariates. Covariates included were prognostic factors for breast cancer survival, that is, age, stage, grade and ER and p53 protein expression. In order to run models including all patients, missing value categories were included for each separate variable with missing information. Polymorphisms were included as categorical variables (with the homozygous common allele group as reference), or as a continuous variable in the per-allele analyses. All pooled analyses were adjusted for study, that is, ABCS, HABCS, HEBCS, $\mathrm{SEARCH}$, included as a categorical variable. Breast cancerspecific survival was defined as survival until death from breast cancer, with breast cancer being the underlying cause of death; death due to other causes was censored (these analy- 


\begin{tabular}{|c|c|c|c|c|c|c|}
\hline $\begin{array}{l}\text { Contributing } \\
\text { studies }\end{array}$ & Design & $\begin{array}{l}\text { Description of } \\
\text { case subjects } \\
\text { and } \\
\text { ascertainment } \\
\text { (age range) }\end{array}$ & $\begin{array}{l}\text { Participation } \\
\text { rates }\end{array}$ & Follow-up & P53 IHC* & $\begin{array}{l}\text { Genotyping } \\
\text { platform(s) } \\
{[38-40]}\end{array}$ \\
\hline $\begin{array}{l}\text { ABCS: } \\
\text { Amsterdam Breast } \\
\text { Cancer Study, The } \\
\text { Netherlands [41] }\end{array}$ & $\begin{array}{l}\text { Hospital-based } \\
\text { consecutive cases }\end{array}$ & $\begin{array}{l}\text { All operable } \\
\text { breast cancer } \\
\text { patients aged < } \\
50 \text { years } \\
\text { diagnosed 1974- } \\
1994 \text { in four } \\
\text { Dutch hospitals } \\
\text { (Amsterdam and } \\
\text { Leiden) ( } 23 \text { to } 50 \\
\text { years) }\end{array}$ & $\begin{array}{l}\text { All patients with } \\
\text { paraffin- } \\
\text { embedded tissue } \\
\text { blocks available } \\
\text { (normal tissue) } \\
\text { from the } \\
\text { Pathology } \\
\text { archives and } \\
\text { successful DNA } \\
\text { isolation } \\
\text { (approximately } \\
85 \%)\end{array}$ & $\begin{array}{l}\text { Active follow-up } \\
\text { through the } \\
\text { medical registries } \\
\text { and general } \\
\text { practitioners }\end{array}$ & $\begin{array}{l}\text { By IHC staining of } \\
\text { TMAs* as } \\
\text { previously } \\
\text { described [25]; } \\
\text { p53 positive } \\
\text { defined as }>10 \% \\
\text { of cells with } \\
\text { positive nuclear } \\
\text { staining. }\end{array}$ & Taqman \\
\hline $\begin{array}{l}\text { HABCS: } \\
\text { Germany: } \\
\text { Hannover Breast } \\
\text { Cancer Study and } \\
\text { bilateral breast } \\
\text { cancer patients } \\
{[42,43]}\end{array}$ & $\begin{array}{l}\text { Hospital-based } \\
\text { case-control } \\
\text { studies }\end{array}$ & $\begin{array}{l}\text { Case patients who } \\
\text { received } \\
\text { radiotherapy for } \\
\text { breast cancer at } \\
\text { Hannover Medical } \\
\text { School between } \\
1997 \text { and } 2003 \\
\text { (27 to } 91 \text { years) }\end{array}$ & $\begin{array}{l}\text { Approximately } \\
80 \% \text { of case } \\
\text { subjects } \\
\text { contacted agreed } \\
\text { to give a blood } \\
\text { sample }\end{array}$ & $\begin{array}{l}\text { Active follow-up at } \\
\text { the Department of } \\
\text { Radiation } \\
\text { Oncology, } \\
\text { Hannover Medical } \\
\text { School }\end{array}$ & NA & $\begin{array}{l}\text { Restriction } \\
\text { enzyme-based } \\
\text { assays }\end{array}$ \\
\hline $\begin{array}{l}\text { HEBCS: } \\
\text { Helsinki Breast } \\
\text { Cancer Study } \\
{[10,44]}\end{array}$ & $\begin{array}{l}\text { Hospital-based } \\
\text { case-control study }\end{array}$ & $\begin{array}{l}\text { Consecutive } \\
\text { incident cases } \\
\text { from the } \\
\text { Department of } \\
\text { Oncology, } \\
\text { Helsinki University } \\
\text { Central Hospital } \\
1997-1998 \\
\text { (22 to } 96 \text { years) }\end{array}$ & $\begin{array}{l}79 \% \text { of the case } \\
\text { subjects }\end{array}$ & $\begin{array}{l}\text { Active follow-up of } \\
\text { the medical } \\
\text { records until five } \\
\text { years and annual } \\
\text { linkage to the } \\
\text { nation-wide } \\
\text { Finnish Cancer } \\
\text { Registry }\end{array}$ & $\begin{array}{l}\text { By } \mathrm{IHC} \text { staining of } \\
\text { TMAs* as } \\
\text { previously } \\
\text { described [10] } \\
\text { and data for } 23 \\
\text { cases derived } \\
\text { from the pathology } \\
\text { reports; p53 } \\
\text { positive defined as } \\
>20 \% \text { of cells } \\
\text { with positive } \\
\text { nuclear staining. }\end{array}$ & $\begin{array}{l}\text { RFLP (MDM2 } \\
\text { SNP309) } \\
\text { Amplifluor(tm) } \\
\text { fluorescent } \\
\text { genotyping } \\
\text { (Kbiosciences) } \\
\text { (TP53 R72P) }\end{array}$ \\
\hline $\begin{array}{l}\text { SEARCH: Studies } \\
\text { of Epidemiology } \\
\text { and Risk Factors } \\
\text { in Cancer } \\
\text { Heredity, } \\
\text { Cambridge, UK } \\
\text { [45] }\end{array}$ & $\begin{array}{l}\text { Population-based } \\
\text { case-control study }\end{array}$ & $\begin{array}{l}\text { Two groups of } \\
\text { case patients } \\
\text { (prevalent and } \\
\text { incident) identified } \\
\text { through East } \\
\text { Anglian Cancer } \\
\text { Registry: patients } \\
\text { diagnosed before } \\
\text { age } 55 \text { years in } \\
1991 \text { to } 1996 \text { and } \\
\text { still alive when } \\
\text { study started in } \\
1996 \text { and patients } \\
\text { diagnosed before } \\
\text { age } 70 \text { years } \\
\text { since } 1996 \text { ( } 25 \text { to } \\
65 \text { years) }\end{array}$ & $\begin{array}{l}64 \% \text { of eligible } \\
\text { case subjects } \\
\text { provided a blood } \\
\text { sample }\end{array}$ & $\begin{array}{l}\text { Combination of } \\
\text { passive follow-up } \\
\text { through national } \\
\text { death registrations } \\
\text { and active follow } \\
\text { up every five years } \\
\text { by the cancer } \\
\text { registry }\end{array}$ & NA & Taqman \\
\hline
\end{tabular}

${ }^{\star} \mathrm{IHC}=$ immunohistochemistry; TMA $=$ Tissue Micro Array; NA = not applicable (no p53 data available).

ses included the ABCS and HEBCS studies, see Table 1). Overall survival was defined as survival until death of any cause. In all analyses, follow-up time was censored at 10 years. All statistical tests used were two-sided and $P$ values $<$ 0.05 were considered statistically significant. All analyses were performed using SPSS 15.0 (SPSS Inc, Chicago, IL, USA).

\section{Results}

\section{Patient characteristics}

Breast cancer patients with follow-up and TP53 R72P and MDM2 SNP309 genotypes from three hospital-based and one population-based study within the Breast Cancer Association Consortium were included for analysis ( $n=3,749$ ) (Table 1). Frequencies of TP53 R72P and MDM2 SNP309 and clinicopathologic characteristics of the breast cancer patients in the four studies are shown in Table 2. We have described and discussed earlier the small difference in MDM2 
Table 2

Germ-line variants and clinicopathologic characteristics of breast cancer patients by study

\begin{tabular}{|c|c|c|c|c|c|c|c|c|c|c|}
\hline & & \multicolumn{2}{|l|}{$\begin{array}{c}\text { ABCS } \\
N=1076\end{array}$} & \multicolumn{2}{|l|}{$\begin{array}{l}\text { HABCS } \\
\mathrm{N}=152 \\
\end{array}$} & \multicolumn{2}{|l|}{$\begin{array}{l}\text { HEBCS } \\
\mathrm{N}=599\end{array}$} & \multicolumn{2}{|l|}{$\begin{array}{l}\text { SEARCH } \\
\mathrm{N}=1922 \\
\end{array}$} & \multirow[t]{2}{*}{$P$ value* } \\
\hline & & $\mathrm{N}$ & $\%$ & $\mathrm{~N}$ & $\%$ & $\mathrm{~N}$ & $\%$ & $\mathrm{~N}$ & $\%$ & \\
\hline \multirow[t]{3}{*}{ MDM2 SNP309 } & TT & 444 & 41.3 & 55 & 36.2 & 183 & 30.6 & 774 & 40.3 & \\
\hline & GT & 487 & 45.3 & 73 & 48.0 & 311 & 51.9 & 913 & 47.5 & \\
\hline & GG & 145 & 13.5 & 24 & 15.8 & 105 & 17.5 & 235 & 12.2 & $<0.001$ \\
\hline \multirow[t]{3}{*}{ TP53 R72P } & GG & 570 & 53.0 & 85 & 55.9 & 314 & 52.4 & 1052 & 54.7 & \\
\hline & GC & 422 & 39.2 & 55 & 36.2 & 236 & 39.4 & 733 & 38.1 & \\
\hline & $\mathrm{CC}$ & 84 & 7.8 & 12 & 7.9 & 49 & 8.2 & 137 & 7.1 & 0.9 \\
\hline \multirow[t]{4}{*}{ Stage } & 1 & 341 & 31.9 & 83 & 69.2 & 205 & 36.9 & 861 & 52.4 & \\
\hline & 2 & 581 & 54.4 & 36 & 30.0 & 295 & 53.1 & 713 & 43.4 & \\
\hline & 3 & 146 & 13.7 & 1 & 0.8 & 56 & 10.1 & 69 & 4.2 & $<0.001$ \\
\hline & Missing & 8 & & 32 & & 43 & & 279 & & \\
\hline \multirow{4}{*}{$\begin{array}{l}\text { Differentiation } \\
\text { grade }\end{array}$} & 1 & 338 & 35.8 & 9 & 8.7 & 138 & 24.6 & 368 & 25.4 & \\
\hline & 2 & 317 & 33.6 & 55 & 53.4 & 243 & 43.2 & 647 & 44.7 & \\
\hline & 3 & 288 & 30.5 & 39 & 37.9 & 181 & 32.2 & 431 & 29.8 & $<0.001$ \\
\hline & Missing & 133 & & 49 & & 37 & & 476 & & \\
\hline \multirow[t]{3}{*}{ ER status tumor } & Negative & 240 & 34.2 & 18 & 15.4 & 135 & 23.2 & 175 & 19.8 & \\
\hline & Positive & 461 & 65.8 & 99 & 84.6 & 446 & 76.8 & 708 & 80.2 & $<0.001$ \\
\hline & Missing & 375 & & 35 & & 18 & & 1039 & & \\
\hline \multirow[t]{3}{*}{ p53 status tumor } & Negative & 473 & 70.4 & & & 335 & 76.7 & & & \\
\hline & Positive & 199 & 29.6 & & & 102 & 23.3 & & & 0.02 \\
\hline & Missing & 404 & & 152 & & 162 & & 1922 & & \\
\hline \multirow{3}{*}{$\begin{array}{l}\text { Vital status } \\
\text { patient }\end{array}$} & Alive & 694 & 64.5 & 129 & 84.9 & 462 & 77.1 & 1596 & 83.0 & \\
\hline & Deceased, all & 382 & 35.5 & 23 & 15.1 & 137 & 22.9 & 326 & 17.0 & $<0.001$ \\
\hline & $\begin{array}{l}\text { Deceased, breast } \\
\text { cancer }\end{array}$ & 337 & & 20 & & 105 & & & & \\
\hline $\begin{array}{l}\text { Years of } \\
\text { diagnosis }\end{array}$ & Range & 1974 to 1994 & & 1997 to 2003 & & 1997 to 1998 & & 1991 to 1996 & & \\
\hline Age at diagnosis & Mean \pm SD & 42.8 & 5.2 & 56.8 & 11.3 & 56.4 & 12.8 & 50.1 & 7.7 & $<0.001$ \\
\hline Follow-up & Mean \pm SD & 10.5 & 5.7 & 6.5 & 1.9 & 7.3 & 2.1 & 6.3 & 2.1 & $<0.001$ \\
\hline
\end{tabular}

* $P$ value of comparison of either categories of non-missing data among studies (by chi-square) or comparison of continuous data (by t-test). 
SNP309 allele frequencies between European populations [1] while difference in patient characteristics between studies can mostly be attributed to differences in patient selection criteria (Table 1). Mean follow-up was 7.7 years (SD 4). A small number patients $(n=26)$ were carriers of the homozygous rare variants for both polymorphisms (Table 3 ).

\section{Breast cancer survival by TP53 R72P, MDM2 SNP309 genotype, and p53 tumor status}

Overall survival of patients did not differ by carriership of either germ-line variant, R72P or SNP309, alone in the pooled analyses (Table 4). Tumor p53 status was available for 1109 patients from the ABCS and HEBCS series (Table 1). In both series, the patients with p53-positive tumors showed poorer overall survival than the patients with $p 53$-negative tumors (pooled HR 1.5 (1.2-1.9), $P=0.002$; Table 4).

\section{Differential effect of TP53 R72P on breast cancer survival stratified for $\mathrm{p} 53$ tumor status}

In the patient group with p53-negative tumors, the actuarial breast cancer-specific survival for the patients carrying the TP53 CC genotype (Pro/Pro) was worse, though not statistically significantly, at 10 years of follow-up as compared to those carrying TP53 GG/GC (Arg/Arg; Arg/Pro) (71\% versus $80 \% P=0.07$; Figure 1). The interaction terms between $\mathrm{p} 53$ expression and TP53 R72P were not significant in a multivariate Cox regression analysis, but considering the difference seen in the actuarial curves we still considered it useful to perform Cox analyses stratified for p53 expression. Patients with the TP53 CC genotype had worse breast-cancer specific survival (HR adjusted for study, age, stage, grade and ER: 1.79 (1.05 to $3.05, P=0.03$ ) (Table 5). Results for overall survival were in line with those of breast-cancer specific survival, but did not reach statistical significance $(P=0.06$, Table 5).

Within the patient group with p53-positive tumors, breast cancer-specific survival stratified by TP53 R72P seemed to show inconsistent results between studies though none were significant, that is, per allele HR (adjusted for age, stage, grade and ER) in the ABCS study was 0.74 ( 0.45 to 1.22 ) and in the HEBCS study 1.46 (0.79 to 2.69). The pooled HR (adjusted for study, age, stage, grade and ER) was 0.82 ( 0.53 to 1.27 )

Table 3

Frequencies of TP53 R72P and MDM2 SNP309 germ-line variants

\begin{tabular}{|c|c|c|c|c|c|c|}
\hline \multirow[t]{2}{*}{ TP53 R72P } & \multicolumn{2}{|c|}{ GG } & \multicolumn{2}{|c|}{ GC } & \multicolumn{2}{|c|}{$\mathrm{CC}$} \\
\hline & $\mathbf{N}$ & $\%$ & $\mathrm{~N}$ & $\%$ & $\mathrm{~N}$ & $\%$ \\
\hline MDM2 SNP309 TT & 799 & 54.9 & 546 & 37.5 & 111 & 7.6 \\
\hline GT & 940 & 52.7 & 699 & 39.2 & 145 & 8.1 \\
\hline GG & 282 & 55.4 & 201 & 39.5 & 26 & 5.1 \\
\hline
\end{tabular}

for heterozygous and 0.86 (0.34 to 2.18 ) for homozygous Callele carriers (Table 5). There was no evidence for a differential effect of MDM2 SNP309 by p53 tumor status on survival (Table 5).

\section{Combined effects of TP53 R72P and MDM2 SNP309 on breast cancer survival}

MDM2 SNP309 showed a differential actuarial overall survival stratified by TP53 R72P in the pooled analyses $(n=3,749)$, that is, homozygous carriers of the G-allele in MDM2 had worse survival within the group of TP53 GC carriers (GG: $65 \%$ versus GT: $72 \%$ and TT: $76 \%, P=0.006$; Figure 2). The same trend was visible in the TP53 homozygous CC group (n $=26 \mathrm{GG} / \mathrm{CC}$ ), but this was not statistically significant. Within the TP53 C-allele carriers combined, MDM2 GG carriers had significantly worse survival compared to TT/TG carriers: $64 \%$ versus $75 \%, P=0.001$. In multivariate analyses (adjusting for study, age, stage, grade and ER) the interaction term for TP53 GC and MDM2 GG was significant $(P=0.028)$, also if additional interaction terms for TP53 R72P and p53 expression were included $(P=0.027)$. The multivariate models (adjusting for study, age, stage, grade and ER) stratified for TP53 R72P (analogue to Figure 2) showed that MDM2 GG carriers had significantly worse survival compared with MDM2 TT carriers only within the TP53 C-allele carriers; more specifically, within TP53 CG carriers: HR 1.43 (1.05 to 1.96), $P=0.02$; within TP53 CC carriers HR 1.39 (0.56 to 3.48), $P=0.48$ (Table 6); within TP53 CG and CC carriers combined: HR (adjusted for study, age, stage, grade and ER) 1.46 (1.09 to 1.96), $P=$ 0.01 .

\section{Discussion}

In the survival analyses including 3,749 breast cancer patients from Finland, The Netherlands, Germany and United Kingdom, we showed combined effects of two germ-line polymorphisms, TP53 R72P, MDM2 SNP309, and p53 tumor expression (by immunohistochemistry). Firstly, we confirmed our earlier observation in Finnish patients [10] that TP53 R72P homozygous carriership predicts a worse survival in patients with p53-negative tumors, also when adjusted for clinical prognostic variables. Thus, in the absence of inactivating p53 mutations in the tumor, the $72 \mathrm{P}$ variant form of $\mathrm{p} 53$ protein may have a compromising effect on the p53 apoptotic function, leading to reduced survival of the patients. Similarly, a study of 414 Chinese breast cancer patients reported that the $72 \mathrm{P}$ homozygous (CC) genotype was associated with both poorer five-year overall survival (five to eight percentile difference, $P=0.04$ ) and poorer disease-free survival among the patients with a wild-type p53 in their tumors $(n=346)$ [16]. In line with other studies published we did not observe an effect of carriership of R72P alone on survival of patients [12-16].

No significant difference in survival by TP53 R72P carriership was observed among the patients with p53-positive tumors, who showed a worse survival overall compared to p53-nega- 
Table 4

HR estimates of overall survival ${ }^{*}$ by TP53 R72P, MDM2 SNP309 and p53

\begin{tabular}{|c|c|c|c|c|}
\hline TP53 R72P** & HR & \multicolumn{2}{|c|}{ Lower and upper limit $95 \% \mathrm{Cl}$} & $P$ value \\
\hline \multicolumn{5}{|l|}{ ABCS } \\
\hline GC & 0.99 & 0.79 & 1.26 & 0.95 \\
\hline $\mathrm{CC}$ & 0.72 & 0.45 & 1.16 & 0.17 \\
\hline \multicolumn{5}{|l|}{ HABCS } \\
\hline GC & 1.40 & 0.60 & 3.45 & 0.46 \\
\hline $\mathrm{CC}$ & 2.54 & 0.69 & 9.34 & 0.16 \\
\hline \multicolumn{5}{|l|}{ HEBCS } \\
\hline GC & 1.17 & 0.82 & 1.67 & 0.40 \\
\hline $\mathrm{CC}$ & 1.72 & 1.00 & 2.98 & 0.05 \\
\hline \multicolumn{5}{|l|}{ SEARCH } \\
\hline GC & 1.18 & 0.95 & 1.49 & 0.14 \\
\hline CC & 0.93 & 0.59 & 1.48 & 0.77 \\
\hline \multicolumn{5}{|l|}{ Pooled $^{\dagger}$} \\
\hline GC & 1.11 & 0.96 & 1.28 & 0.18 \\
\hline $\mathrm{CC}$ & 1.00 & 0.76 & 1.31 & 0.97 \\
\hline
\end{tabular}

MDM2 SNP309**

\begin{tabular}{|c|c|c|c|c|}
\hline \multicolumn{5}{|l|}{ ABCS } \\
\hline TG & 0.93 & 0.73 & 1.18 & 0.54 \\
\hline GG & 0.99 & 0.70 & 1.40 & 0.97 \\
\hline \multicolumn{5}{|l|}{ HABCS } \\
\hline TG & 0.60 & 0.25 & 1.46 & 0.26 \\
\hline GG & 0.36 & 0.08 & 1.65 & 0.19 \\
\hline \multicolumn{5}{|l|}{ HEBCS } \\
\hline TG & 0.76 & 0.53 & 1.11 & 0.16 \\
\hline GG & 0.91 & 0.56 & 1.47 & 0.69 \\
\hline \multicolumn{5}{|l|}{ SEARCH } \\
\hline TG & 1.03 & 0.82 & 1.31 & 0.78 \\
\hline GG & 1.43 & 1.03 & 1.97 & 0.03 \\
\hline \multicolumn{5}{|l|}{ Pooled $^{+}$} \\
\hline TG & 0.93 & 0.80 & 1.08 & 0.34 \\
\hline GG & 1.11 & 0.90 & 1.37 & 0.31 \\
\hline \multicolumn{5}{|c|}{ p53 status tumor ** } \\
\hline \multicolumn{5}{|l|}{$A B C S$} \\
\hline p53 positive & 1.31 & 0.96 & 1.80 & 0.09 \\
\hline \multicolumn{5}{|l|}{ HEBCS } \\
\hline p53 positive & 1.93 & 1.27 & 2.94 & 0.002 \\
\hline \multicolumn{5}{|l|}{ Pooled $^{\dagger}$} \\
\hline p53 positive & 1.50 & 1.16 & 1.93 & 0.002 \\
\hline \multicolumn{5}{|c|}{$\begin{array}{l}\text { Breast cancer-specific survival } \\
\text { Pooled }^{\dagger}\end{array}$} \\
\hline p53 positive & 1.57 & 1.20 & 2.05 & 0.001 \\
\hline \multicolumn{5}{|c|}{$\begin{array}{l}{ }^{*} \text { Overall survival including all studies unless otherwise specified; }{ }^{* *} \mathrm{HRs} \text { of heterozygous and homozygous rare allele groups have been calculated } \\
\text { by comparison to the reference categories of common alleles: TP53 R72P=GG; MDM2 SNP309=TT; p53= negative tumors; }{ }^{+P o o l e d} \\
\text { analyses have been adjusted for study. }\end{array}$} \\
\hline
\end{tabular}


Figure 1

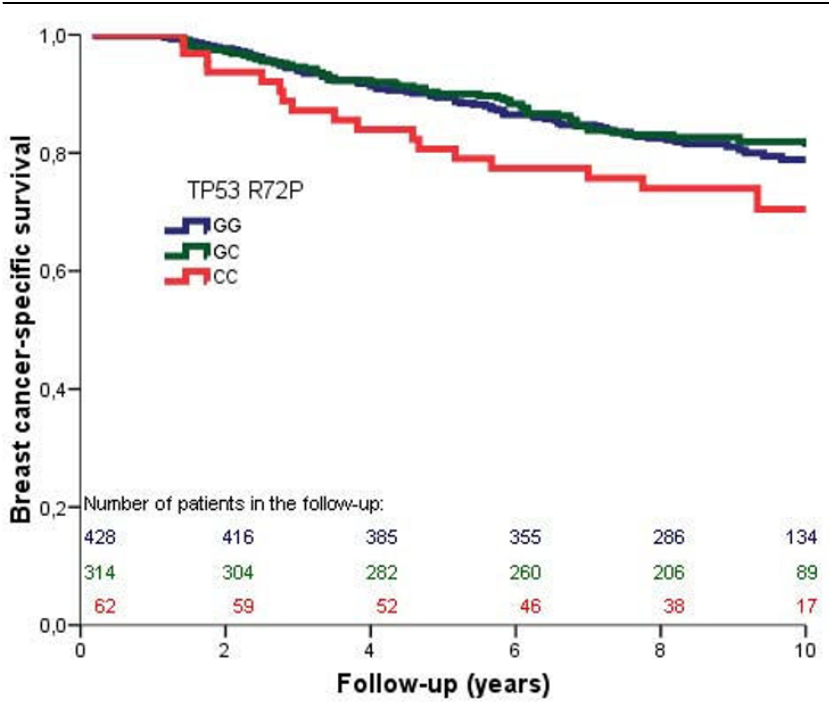

Cumulative breast cancer-specific survival (Kaplan Meier) of breast cancer patients with p53 negative tumors stratified by TP53 R72P. Survival in the TP53 CC group was worse compared to that in the GC and $\mathrm{GG}$ group combined ( $80 \%$ versus $71 \%, P=0.07$ ).

tive tumors. In the pooled analysis, CC homozygote patients with p53-positive tumors even tended to have a better survival. In the study by Xu et al. in Chinese breast cancer patients [16], the CC homozygote patients also had non-significant better survival than the GG homozygotes and heterozygotes within the group of patients with p53-mutated tumors.

The finding of $\mathrm{CC}$ homozygote $(72 \mathrm{P})$ carriers having poorer survival is consistent with the R72 variant of wild-type p53 being a more potent inducer of apoptosis than the wild-type $72 \mathrm{P}$ variant. It has been suggested that R72 homozygotes may respond more favorably to radiation or chemotherapy [27]. Response rate after chemo-radiotherapy of advanced squamous cell carcinomas of head and neck and survival was higher in patients with the R72 allele compared to those with the $72 \mathrm{P}$ allele [28]. These favorable effects of the R72 allele may, however, be reversed by a somatic p53 mutation on this allele, as has been reported in squamous cell carcinomas of head and neck $[29,30]$. In line with this, retention of the R72 allele with loss of the 72P allele in the tumor tissue has been associated with reduced survival in heterozygous breast cancer patients [31].

Carriership of MDM2 SNP309 alone did not affect survival of patients in our study and two other, smaller studies [13,22]. However, we found an 11 percentile survival difference for homozygous MDM2 G-allele carriers within the group of TP53 C-allele $(72 \mathrm{P})$ carriers. Biologically this seems plausible considering the reduced apoptotic function of the TP53 Pro-variant $[6,7]$ and the attenuation of the $\mathrm{p} 53$ pathway by $\mathrm{mdm} 2$, the production of which is increased by the SNP309 G-variant
[17]. In addition, the interaction of both polymorphisms remained statistically significant in multivariate models adjusting for clinical prognostic factors.

We did not observe evidence for a combined effect of SNP309 and p53 tumor expression (as shown here by results of SNP309 stratified by p53 status in Table 5, but obviously p53 did also not have a differential effect on survival stratified by SNP309). This is in contrast to a previous, smaller study (n $=248$ ) in the American population, which suggested that tumor p53 status was associated with breast cancer survival only among patients homozygous for the MDM2 SNP309 Tallele and not among carriers of the variant G-allele [22]. Though our study is one of the largest published studies on combined effects of the germline genetic variation and tumor somatic events, the numbers are still small for looking at such modifying effects on survival.

Many studies have confirmed that mutated p53 is a prognostic factor in breast cancer. The risk of dying of breast cancer for patients with a p53 mutation in their tumor has been estimated to be two to five-fold compared to patients with wild-type p53 tumors [32,33]. Positive immunostaining for p53 is in general considered to indicate somatic p53 mutation and an impaired p53 pathway, though the correlation with TP53 mutations is incomplete $[34,35]$. The accumulation of $p 53$ in the tumors detected by immunohistochemistry was a prognostic marker of poorer survival in both our series with p53 immunohistochemistry data available (the HEBCS and ABCS series). This effect was somewhat stronger in the HEBCS series, which may be explained by the more stringent cut-off used $(20 \%$ positive tumor cells compared to $10 \%$ in the ABCS series).

\section{Conclusions}

We have shown here that TP53 R72P may have additional prognostic value especially among patients with p53-negative tumors. However, the effect of p53 on outcome may be influenced by adjuvant systemic therapy (for example, [31,36], reviewed in Bertheau [37]) and larger studies will be needed to address this question. Our study is one of the few that have shown an interaction of germ-line variants, that is, TP53 R72P and MDM2 SNP309, in breast cancer survival. The results, showing a statistically significant interaction of the p53 Provariant and the GG genotype of MDM2 SNP309, are in line with our a priori biologically-supported hypothesis, which is, the role of enhanced DNA repair function of the Pro-variant, combined with increased expression of the Mdm2 protein, and thus overall attenuation of the p53 pathway in the tumor cells. These results suggest that even subtle differences in p53 apoptotic function caused by synergistic polymorphisms may affect patient's survival, possibly by modifying treatment response. Altogether, our findings are in line with biological evidence in literature, and in the future, may have also clinical significance for models of breast cancer prognosis or treatment. However, because this is the first report on the com- 
Table 5

HR estimates of overall and breast cancer-specific survival by TP53 R72P, in p53 negative and positive tumors (multivariate models)

\begin{tabular}{|c|c|c|c|c|}
\hline TP53 R72P & HR & \multicolumn{2}{|c|}{ Lower and upper limit $95 \% \mathrm{Cl}$} & $P$ value \\
\hline \multicolumn{5}{|c|}{ Overall survival } \\
\hline \multicolumn{5}{|c|}{ p53 negative tumors } \\
\hline GC & 1.11 & 0.80 & 1.52 & 0.54 \\
\hline $\mathrm{CC}$ & 1.63 & 0.97 & 2.74 & 0.06 \\
\hline \multicolumn{5}{|c|}{ p53 positive tumors } \\
\hline GC & 0.82 & 0.53 & 1.27 & 0.37 \\
\hline CC & 0.86 & 0.34 & 2.18 & 0.75 \\
\hline
\end{tabular}

\section{Breast cancer-specific survival}

p53 negative tumors

$\begin{array}{lllrr}\text { GC } & 0.97 & 0.68 & 1.37 & 0.85 \\ \text { CC } & 1.79 & 1.05 & 3.05 & 0.03\end{array}$

p53 positive tumors

$\begin{array}{lllrr}\text { GC } & 0.90 & 0.57 & 1.42 & 0.65 \\ \text { CC } & 1.00 & 0.39 & 2.55 & 1.00\end{array}$

MDM2 SNP309

HR

Lower and upper limit 95\% $\mathrm{Cl}$

$P$ value

Overall survival

p53 negative tumors

\begin{tabular}{|c|c|c|c|c|}
\hline TG & 0.84 & 0.60 & 1.17 & 0.30 \\
\hline GG & 1.28 & 0.85 & 1.94 & 0.24 \\
\hline \multicolumn{5}{|c|}{53 positive tumors } \\
\hline TG & 0.78 & 0.49 & 1.24 & 0.30 \\
\hline GG & 0.78 & 0.41 & 1.48 & 0.45 \\
\hline
\end{tabular}

\section{Breast cancer-specific survival}

p53 negative tumors

\begin{tabular}{|c|c|c|c|c|}
\hline TG & 0.92 & 0.64 & 1.31 & 0.63 \\
\hline GG & 1.41 & 0.90 & 2.19 & 0.13 \\
\hline \multicolumn{5}{|c|}{53 positive tumors } \\
\hline TG & 0.76 & 0.47 & 1.23 & 0.27 \\
\hline GG & 0.69 & 0.35 & 1.39 & 0.30 \\
\hline
\end{tabular}

Pooled analyses for studies with p53 information (ABCS and HEBCS); HRs of heterozygous and homozygous rare allele groups have been calculated by comparison to the reference categories of the homozygous common allele: TP53 R72P = GG, and MDM2 SNP309= TT; analyses have been adjusted for study, age, stage, grade and ER. 


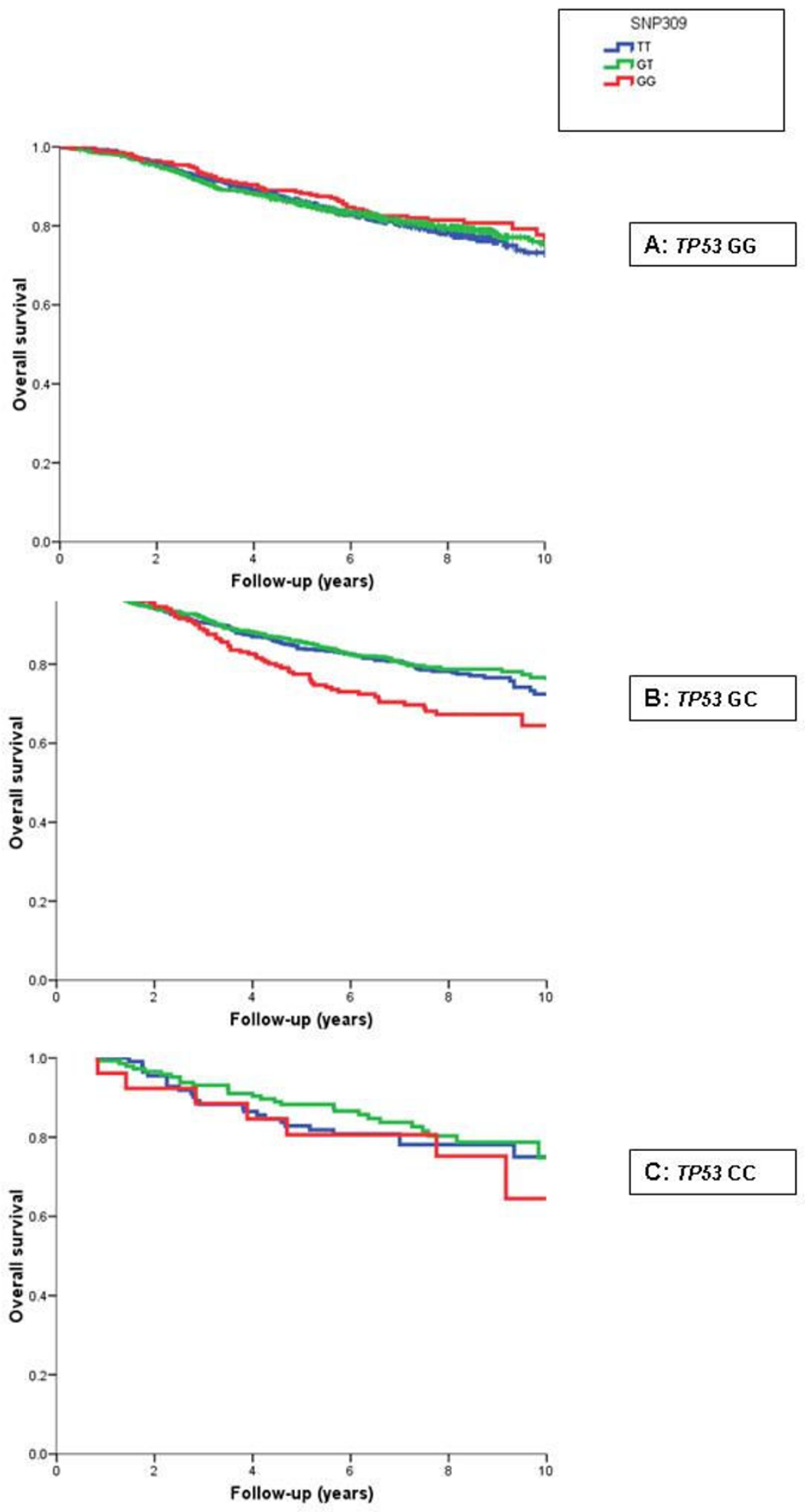

Cumulative overall survival of breast cancer patients by MDM2 SNP309 and TP53 R72P genotypes. Each figure shows Kaplan Meier survival curves of MDM2 SNP309 genotypes within one group of TP53 R72P genotype. (a) TP53 GG genotype (ns); (b) TP53 GC genotype (P=0.006); (c) TP53 CC genotype (ns). The numbers at start of follow-up were: Figure A: TT $n=798$, TG $n=939, G G n=281 ; B$ : TT $n=545$, TG $n=698$, $G G n=200 ; C: T T n=110, T G n=144, G G n=25$. Within the TP53 C-allele carriers (Figure $A$ and $B$ combined), MDM2 GG carriers had significantly worse survival compared to TT/TG carriers combined: $64 \%$ versus $75 \%, P=0.001$. 
HR estimates of multivariate analyses for MDM2 SNP309 stratified by TP53 R72P

\begin{tabular}{|c|c|c|c|c|c|c|c|c|c|c|c|c|}
\hline \multirow[b]{3}{*}{$\begin{array}{l}\text { MDM2 } \\
\text { SNP309 TT }\end{array}$} & HR & \multicolumn{2}{|c|}{$\begin{array}{l}\text { Lower and upper } \\
\text { limit } 95 \% \mathrm{Cl}\end{array}$} & \multirow{2}{*}{$\begin{array}{r}P \\
\text { value } \\
\end{array}$} & HR & \multirow{2}{*}{\multicolumn{3}{|c|}{$\begin{array}{l}\text { Lower and upper } \\
\text { limit } 95 \% \mathrm{Cl}\end{array}$}} & HR & \multirow{2}{*}{\multicolumn{2}{|c|}{$\begin{array}{c}\begin{array}{c}\text { Lower and upper } \\
\text { limit } 95 \% \mathrm{Cl}\end{array} \\
\text { TP53 R72P: CC }\end{array}$}} & \multirow[t]{3}{*}{$\begin{array}{r}P \\
\text { value }\end{array}$} \\
\hline & & \multicolumn{2}{|c|}{ TP53 R72P: GG } & & & & & & & & & \\
\hline & $\begin{array}{r}1.0 \\
\text { (Ref) }\end{array}$ & & & & $\begin{array}{r}1.0 \\
\text { (Ref) }\end{array}$ & & & & $\begin{array}{r}1.0 \\
\text { (Ref) }\end{array}$ & & & \\
\hline TG & .90 & .73 & 1.11 & .33 & .94 & .73 & 1.20 & .61 & .85 & .47 & 1.55 & .60 \\
\hline GG & .85 & .63 & 1.16 & .31 & 1.43 & 1.05 & 1.96 & .02 & 1.39 & .56 & 3.48 & .48 \\
\hline $\begin{array}{l}\text { p53 } \\
\text { negative }\end{array}$ & $\begin{array}{r}1.0 \\
\text { (Ref) }\end{array}$ & & & & $\begin{array}{r}1.0 \\
\text { (Ref) }\end{array}$ & & & & $\begin{array}{r}1.0 \\
\text { (Ref) }\end{array}$ & & & \\
\hline positive & 1.37 & .96 & 1.96 & .08 & .89 & .58 & 1.35 & .57 & .76 & .25 & 2.30 & .63 \\
\hline missing & 1.63 & 1.16 & 2.28 & .005 & 1.66 & 1.13 & 2.44 & .009 & .53 & .21 & 1.34 & .18 \\
\hline Stage 1 & $\begin{array}{r}1.0 \\
\text { (Ref) }\end{array}$ & & & & $\begin{array}{r}1.0 \\
\text { (Ref) }\end{array}$ & & & & $\begin{array}{r}1.0 \\
\text { (Ref) }\end{array}$ & & & \\
\hline 2 & 2.51 & 1.90 & 3.33 & $<.001$ & 2.55 & 1.88 & 3.46 & $<.001$ & 1.48 & .73 & 2.97 & .28 \\
\hline 3 & 7.10 & 5.05 & 9.97 & $<.001$ & 7.56 & 5.18 & 11.02 & $<.001$ & 5.49 & 2.17 & 13.87 & $<.001$ \\
\hline missing & 3.69 & 2.42 & 5.63 & $<.001$ & 2.55 & 1.54 & 4.21 & $<.001$ & 1.60 & .46 & 5.57 & .46 \\
\hline Grade 1 & $\begin{array}{r}1.0 \\
\text { (Ref) }\end{array}$ & & & & $\begin{array}{r}1.0 \\
\text { (Ref) }\end{array}$ & & & & $\begin{array}{r}1.0 \\
\text { (Ref) }\end{array}$ & & & \\
\hline 2 & 1.80 & 1.27 & 2.54 & .001 & 1.12 & .77 & 1.62 & .55 & 3.28 & 1.29 & 8.35 & .01 \\
\hline 3 & 2.63 & 1.84 & 3.76 & $<.001$ & 2.39 & 1.65 & 3.46 & $<.001$ & 4.08 & 1.55 & 10.79 & .005 \\
\hline missing & 1.84 & 1.21 & 2.78 & .004 & 1.391 & .87 & 2.22 & .17 & 2.11 & .64 & 6.92 & .22 \\
\hline ER negative & $\begin{array}{r}1.0 \\
\text { (Ref) }\end{array}$ & & & & $\begin{array}{r}1.0 \\
\text { (Ref) }\end{array}$ & & & & $\begin{array}{r}1.0 \\
\text { (Ref) }\end{array}$ & & & \\
\hline positive & .63 & .48 & .84 & .002 & .61 & .44 & .83 & .002 & .59 & .27 & 1.26 & .17 \\
\hline missing & .65 & .46 & .91 & .01 & .58 & .40 & .84 & .003 & .90 & .36 & 2.25 & .82 \\
\hline Age & 1.02 & 1.01 & 1.03 & .001 & 1.00 & .99 & 1.02 & .54 & 1.01 & .98 & 1.04 & .70 \\
\hline
\end{tabular}

Models have also been adjusted for study.

bined effect of TP53 R72P and MDM2 SNP309 on breast cancer survival and we cannot exclude a chance finding, other studies to confirm this will be necessary. Larger studies will be needed also to investigate the effect of specific treatment modalities on the survival by TP53 R72P and MDM2 SNP309.

\section{Competing interests}

The authors declare that they have no competing interests.

\section{Authors' contributions}

MKS, TD and HN took final responsibility for the decision to submit the paper for publication; all other authors read and approved the manuscript. MKS, JT, FEVL, LJVTV, PDPP, DFE, $\mathrm{TD}, \mathrm{CB}, \mathrm{HN}$ were responsible for the study design. MKS, JT, $A B, M S, M H, T D, S A R, R F$ were responsible for data acquisition and collection. MKS and JT did the data analyses. Data interpretation was carried out by MKS, JT, AB, RF, CB, and $H N$. MKS, AB, TD, CB, and $H N$ wrote the paper. All authors read and approved the manuscript.

\section{Acknowledgements}

We wish to thank Dr Hannaleena Eerola and Dr Kirsimari Aaltonen and Nina Puolakka RN for their help with the Finnish patient data. The Finnish Cancer registry is gratefully acknowledged for the cancer data. The Helsinki study has been financially supported by the Helsinki University 
Central Hospital Research Fund, Academy of Finland (110663), Finnish Cancer Society, the Sigrid Juselius Foundation, and the Ida Montin Foundation. We highly appreciate the contributions of our Dutch colleagues at the NKI-AVL, among others Renate Udo, Linde Braaf and Hans Peterse ${ }^{\dagger}$; and at LUMC: Rob Tollenaar, Vincent Smit and Cees Cornelisse; the Dutch study was financed by the Dutch Cancer Society (NKI 2001-2423; 2007-3839) and the Cancer Genomics Center (Dutch Genomics Initiative). We are grateful to our German colleagues Michael Bremer, Andreas Meyer, Johann H. Karstens and Peter Hillemanns for their support of the study at Hannover Medical School. The SEARCH study is funded by Cancer Research UK, and DFE is a Principal Research Fellow and PDP is a Senior Clinical Research Fellow of CRUK.

\section{References}

1. Schmidt MK, Reincke S, Broeks A, Braaf LM, Hogervorst FBL, Tollenaar RAEM, Johnson N, Fletcher O, Peto J, Tommiska J, Blomqvist C, Nevanlinna HA, Healey CS, Dunning AM, Pharoah PD, Easton DF, Dork T, Van't Veer LJ, on behalf of the Breast Cancer Association Consortium: Do MDM2 SNP309 and TP53 R72P Interact in Breast Cancer Susceptibility? A Large Pooled Series from the Breast Cancer Association Consortium. Cancer Res 2007, 67:9584-9590.

2. Fagerholm R, Hofstetter B, Tommiska J, Aaltonen K, Vrtel R, Syrjakoski K, Kallioniemi A, Kilpivaara O, Mannermaa A, Kosma VM, Uusitupa M, Eskelinen M, Kataja V, Aittomaki K, von Smitten K, Heikkila P, Lukas J, Holli K, Bartkova J, Blomqvist C, Bartek J, Nevanlinna H: NAD(P)H:quinone oxidoreductase 1 NOO1*2 genotype (P187S) is a strong prognostic and predictive factor in breast cancer. Nat Genet 2008, 40:844-853.

3. Bond GL, Hu W, Levine AJ: MDM2 is a central node in the p53 pathway: 12 years and counting. Curr Cancer Drug Targets 2005, 5:3-8.

4. Walker KK, Levine AJ: Identification of a novel p53 functional domain that is necessary for efficient growth suppression. Proc Natl Acad Sci USA 1996, 93:15335-15340.

5. Sakamuro D, Sabbatini P, White E, Prendergast GC: The polyproline region of p53 is required to activate apoptosis but not growth arrest. Oncogene 1997, 15:887-898.

6. Thomas M, Kalita A, Labrecque S, Pim D, Banks L, Matlashewski G: Two polymorphic variants of wild-type p53 differ biochemically and biologically. Mol Cell Biol 1999, 19:1092-1100.

7. Pim $D$, Banks $L$ : $\mathbf{p 5 3}$ polymorphic variants at codon $\mathbf{7 2}$ exert different effects on cell cycle progression. Int J Cancer 2004, 108:196-199.

8. Bergamaschi $D$, Samuels $Y$, Sullivan A, Zvelebil $M$, Breyssens $H$, Bisso A, Del Sal G, Syed N, Smith P, Gasco M, Crook T, Lu X: iASPP preferentially binds p53 proline-rich region and modulates apoptotic function of codon 72-polymorphic p53. Nat Genet 2006, 38:1133-1141.

9. Siddique MM, Balram C, Fiszer-Maliszewska L, Aggarwal A, Tan A, Tan P, Soo KC, Sabapathy K: Evidence for selective expression of the p53 codon 72 polymorphs: implications in cancer development. Cancer Epidemiol Biomarkers Prev 2005, 14:2245-2252

10. Tommiska J, Eerola $H$, Heinonen $M$, Salonen L, Kaare M, Tallila J, Ristimaki A, von Smitten K, Aittomaki K, Heikkila P, Blomqvist C, Nevanlinna H: Breast Cancer Patients with p53 Pro72 Homozygous Genotype Have a Poorer Survival. Clin Cancer Res 2005, 11:5098-5103.

11. The Breast Cancer Association Consortium: Commonly Studied Single-Nucleotide Polymorphisms and Breast Cancer: Results From the Breast Cancer Association Consortium. J Nat/ Cancer Inst 2006, 98:1382-1396.

12. Goode E, Dunning A, Kuschel B, Healey C, Day N, Ponder B, Easton D, Pharoah P: Effect of Germ-Line Genetic Variation on Breast Cancer Survival in a Population-based Study. Cancer Res 2002, 62:3052-3057.

13. Toyama $T$, Zhang Z, Nishio M, Hamaguchi M, Kondo N, Iwase $H$, Iwata $\mathrm{H}$, Takahashi S, Yamashita H, Fujii Y: Association of TP53 codon 72 polymorphism and the outcome of adjuvant therapy in breast cancer patients. Breast Cancer Res 2007, 9:R34.
14. Xu Y, Yao L, Ouyang T, Li J, Wang T, Fan Z, Lin B, Lu Y, Xie Y: p53 Codon 72 Polymorphism Predicts the Pathologic Response to Neoadjuvant Chemotherapy in Patients with Breast Cancer. Clin Cancer Res 2005, 11:7328-7333.

15. Kyndi M, Alsner J, Hansen LL, Sorensen FB, Overgaard J: LOH rather than genotypes of TP53 codon 72 is associated with disease-free survival in primary breast cancer. Acta Oncol 2006, 45:602-609.

16. Xu Y, Yao L, Zhao A, Ouyang T, Li J, Wang T, Fan Z, Fan T, Lin B, Lu Y, Xie Y: Effect of p53 codon $\mathbf{7 2}$ genotype on breast cancer survival depends on p53 gene status. Int J Cancer 2008, 122:2761-2766.

17. Bond GL, Hu W, Bond EE, Robins H, Lutzker SG, Arva NC, Bargonetti J, Bartel F, Taubert H, Wuerl P, Onel K, Yip L, Hwang SJ, Strong LC, Lozano G, Levine AJ: A single nucleotide polymorphism in the MDM2 promoter attenuates the p53 tumor suppressor pathway and accelerates tumor formation in humans. Cell 2004, 119:591-602.

18. Bougeard G, Baert-Desurmont S, Tournier I, Vasseur S, Martin C, Brugieres L, Chompret A, Bressac-de Paillerets B, Stoppa-Lyonnet D, Bonaiti-Pellie C, Frebourg T: Impact of the MDM2 SNP309 and p53 Arg72Pro polymorphism on age of tumour onset in LiFraumeni syndrome. J Med Genet 2006, 43:531-533.

19. Ruijs MWG, Schmidt MK, Nevanlinna H, Tommiska J, Aittomäki K, Pruntel R, Verhoef S, Van't Veer LJ: The single nucleotide polymorphism 309 in the MDM2 gene contributes to the Li-Fraumeni syndrome and related phenotypes. Eur J Hum Genet 2007, 15:110-114.

20. Wasielewski M, Nagel JH, Brekelmans C, Klijn JG, Ouweland A van den, Meijers-Heijboer H, Schutte M: MDM2 SNP309 accelerates familial breast carcinogenesis independently of estrogen signaling. Breast Cancer Res Treat 2006, 104:153-175.

21. Cox DG, Deer D, Guo Q, Tworoger SS, Hankinson SE, Hunter DJ, De Vivo I: The p53 Arg72Pro and MDM2 -309 polymorphisms and risk of breast cancer in the nurses' health studies. Cancer Causes Control 2007, 18:621-625.

22. Boersma B, Howe T, Goodman J, Yfantis H, Lee D, Chanock S, Ambs S: Association of Breast Cancer Outcome With Status of p53 and MDM2 SNP309. J Natl Cancer Inst 2006, 98:911-919.

23. Gryshchenko I, Hofbauer $S$, Stoecher $M$, Daniel $P$, Steurer $M$, Gaiger A, Eigenberger K, Greil R, Tinhofer I: MDM2 SNP309 Is Associated With Poor Outcome in B-Cell Chronic Lymphocytic Leukemia. J Clin Oncol 2008, 26:2252-2257.

24. Nechushtan H, Hamburger T, Mendelson S, Kadouri L, Sharon N, Pikarsky E, Peretz T: Effects of the single nucleotide polymorphism at MDM2 309 on breast cancer patients with/without BRCA1/2 mutations. BMC Cancer 2009, 9:60.

25. Garcia-Closas M, Hall P, Nevanlinna H, Pooley K, Morrison J, Richesson DA, Bojesen SE, Nordestgaard BG, Axelsson CK, Arias J, Milne RL, Ribas G, Gonzalez-Neira A, Benitez J, Zamora P, Brauch $\mathrm{H}$, Justenhoven C, Hamann U, Ko YD, Bruening T, Haas S, Dork T, Schurmann $P$, Hillemanns $P$, Bogdanova N, Bremer M, Karstens $\mathrm{JH}$, Fagerholm R, Aaltonen K, Aittomaki K: Heterogeneity of breast cancer associations with five susceptibility Loci by clinical and pathological characteristics. PLoS Genet 2008 4:e1000054.

26. McShane LM, Altman DG, Sauerbrei W, Taube SE, Gion M, Clark GM: Reporting recommendations for tumor marker prognostic studies. J Clin Oncol 2005, 23:9067-9072.

27. Dumont P, Leu JI, Della Pietra AC III, George DL, Murphy M: The codon 72 polymorphic variants of p53 have markedly different apoptotic potential. Nat Genet 2003, 33:357-365.

28. Sullivan A, Syed N, Gasco M, Bergamaschi D, Trigiante G, Attard $M$, Hiller L, Farrell PJ, Smith P, Lu X, Crook T: Polymorphism in wild-type p53 modulates response to chemotherapy in vitro and in vivo. Oncogene 2004, 23:3328-3337.

29. Bergamaschi D, Gasco M, Hiller L, Sullivan A, Syed N, Trigiante G, Yulug I, Merlano M, Numico G, Comino A, Attard M, Reelfs O, Gusterson B, Bell AK, Heath V, Tavassoli M, Farrell PJ, Smith P, Lu $X$, Crook T: p53 polymorphism influences response in cancer chemotherapy via modulation of p73-dependent apoptosis. Cancer Cell 2003, 3:387-402.

30. Schneider-Stock R, Mawrin C, Motsch C, Boltze C, Peters B, Hartig R, Buhtz P, Giers A, Rohrbeck A, Freigang B, Roessner A: Retention of the arginine allele in codon 72 of the p53 gene correlates with poor apoptosis in head and neck cancer. Am J Pathol 2004, 164:1233-1241. 
31. Bonafe M, Ceccarelli C, Farabegoli F, Santini D, Taffurelli M, Barbi C, Marzi E, Trapassi C, Storci G, Olivieri F, Franceschi C: Retention of the p53 Codon 72 Arginine Allele Is Associated with a Reduction of Disease-Free and Overall Survival in Arginine/ Proline Heterozygous Breast Cancer Patients. Clin Cancer Res 2003, 9:4860-4864.

32. Olivier M, Langerod A, Carrieri P, Bergh J, Klaar S, Eyfjord J, Theillet C, Rodriguez C, Lidereau R, Bieche I, Varley J, Bignon Y, Uhrhammer N, Winqvist R, Jukkola-Vuorinen A, Niederacher D, Kato S, Ishioka $C$, Hainaut $P$, Borresen-Dale A: The Clinical Value of Somatic TP53 Gene Mutations in 1,794 Patients with Breast Cancer. Clin Cancer Res 2006, 12:1157-1167.

33. Petitjean A, Achatz Ml, Borresen-Dale AL, Hainaut $P$, Olivier $M$ : TP53 mutations in human cancers: functional selection and impact on cancer prognosis and outcomes. Oncogene 2007, 26:2157-2165.

34. Soussi T, Beroud C: Assessing TP53 status in human tumours to evaluate clinical outcome. Nat Rev Cancer 2001, 1:233-240.

35. Sjogren S, Inganas M, Norberg T, Lindgren A, Nordgren H, Holmberg $L$, Bergh J: The p53 gene in breast cancer: prognostic value of complementary DNA sequencing versus immunohistochemistry. J Natl Cancer Inst 1996, 88:173-182.

36. Bidard FC, Matthieu MC, Chollet P, Raoefils I, Abrial C, Domont J, Spielmann M, Delaloge S, Andre F, Penault-Llorca F: p53 status and efficacy of primary anthracyclines/alkylating agent-based regimen according to breast cancer molecular classes. Ann Oncol 2008, 19:1261-1265.

37. Bertheau P, Espie M, Turpin E, Lehmann J, Plassa LF, Varna M, Janin A, de The H: TP53 status and response to chemotherapy in breast cancer. Pathobiology 2008, 75:132-139.

38. Kbiosciences, Cambridge, UK [http://www.kbioscience.co.uk]

39. Taqman, Applied Biosystems [http://www2.appliedbiosys tems.com]

40. Illumina [http://www.illumina.com]

41. Schmidt MK, Tollenaar RAEM, de Kemp SR, Broeks A, Cornelisse CJ, Smit VTHBM, Peterse JL, van Leeuwen FE, Van't Veer LJ: Breast Cancer Survival and Tumor Characteristics in Premenopausal Women Carrying the CHEK2*1100delC Germline Mutation. J Clin Oncol 2007, 25:64-69.

42. Steinmann $D$, Bremer $M$, Rades $D$, Skawran $B$, Siebrands $C$, Karstens JH, Dork T: Mutations of the BRCA1 and BRCA2 genes in patients with bilateral breast cancer. $\mathrm{Br} J$ Cancer 2001, 85:850-858.

43. Dork T, Bendix R, Bremer M, Rades D, Klopper K, Nicke M, Skawran B, Hector A, Yamini P, Steinmann D, Weise S, Stuhrmann $\mathrm{M}$, Karstens $\mathrm{JH}$ : Spectrum of ATM gene mutations in a hospital-based series of unselected breast cancer patients. Cancer Res 2001, 61:7608-7615.

44. Syrjakoski $K$, Vahteristo $P$, Eerola $H$, Tamminen A, Kivinummi $K$, Sarantaus L, Holli K, Blomqvist C, Kallioniemi OP, Kainu T, Nevanlinna $\mathrm{H}$ : Population-based study of BRCA1 and BRCA2 mutations in 1035 unselected Finnish breast cancer patients. J Natl Cancer Inst 2000, 92:1529-1531.

45. Cebrian $A$, Pharoah $P$, Ahmed $S$, Ropero $S$, Fraga $M$, Smith $P$, Conroy D, Luben R, Perkins B, Easton D, Dunning A, Esteller M, Ponder B: Genetic variants in epigenetic genes and breast cancer risk. Carcinogenesis 2006, 27:1661-1669. 